\title{
Effect of peracetic acid used as single irrigant on the smear layer, adhesion, and penetrability of AH Plus
}

\author{
Katia Cristina KEINE ${ }^{(a)}(1)$ \\ Milton Carlos KUGA(a) \\ Fernanda Borges Cunha TORMIN(a) \\ Ana Carolina VENÇÃO'(a) \\ Marco Antonio Hungaro DUARTE(b) \\ Gisselle Moraima CHÁVEZ-ANDRADE(a) \\ Gisele FARIA(a) (iD \\ (a) Department of Restorative Dentistry, UNESP \\ - São Paulo State University, School of \\ Dentistry, Araraquara, SP, Brazil. \\ (b)Department of Restorative Dentistry, Dental \\ Materials and Endodontics, University of \\ São Paulo, School of Dentistry, Bauru, \\ São Paulo,
}

Declaration of Interests: The authors certify that they have no commercial or associative interest that represents a conflict of interest in connection with the manuscript.

Corresponding Author:

Gisele Faria

E-mail: gisele.faria@unesp.br

hitps://doi.org/10.1590/1807-3107bor-2019.vol33.0057

Submitted: November 19, 2018

Accepted for publication: May 14, 2019

Last revision: June 12, 2019

\begin{abstract}
The aim of this study was to evaluate the effect of peracetic acid (PAA) as a single irrigant on the smear layer, on the intraradicular dentinal bond strength, and on the penetrability of an epoxy-based resin sealer into the dentinal tubules. A total of 120 roots were distributed into 4 groups according to the irrigant used in root canal preparation: $1 \%$ PAA (PAA); $2.5 \% \mathrm{NaOCl}$ followed by final irrigation with $17 \%$ EDTA and 2.5\% NaOCl (NaOCl-EDTA-NaOCl); $2.5 \% \mathrm{NaOCl}$ $(\mathrm{NaOCl})$; and saline solution (SS). The smear layer was evaluated using scanning electron microscopy. The bond strength of an epoxy-based resin sealer (AH Plus) to root dentin was evaluated by the push-out test and penetrability of the sealer into dentinal tubules was observed by confocal laser microscopy. The results were analyzed by the Kruskal-Wallis and the Dunn post-test $(\alpha=0.05)$. The use of $1 \%$ PAA as single root canal irrigant provided smear layer removal and improved the penetrability and bond strength of AH Plus to root dentin in a manner similar to that of the NaOCl-EDTA-NaOCl group $(\mathrm{p}>0.05)$. The $\mathrm{NaOCl}$ and SS groups had higher values of smear layer and lower values of sealer penetrability and dentin bond strength than the PAA and NaOCl-EDTA-NaOCl groups $(\mathrm{p}<0.05)$. Thus, $1 \%$ PAA has the potential to be used as a single irrigant in root canals.
\end{abstract}

Keywords: Peracetic Acid; Root Canal Irrigants; Smear Layer.

\section{Introduction}

Sodium hypochlorite $(\mathrm{NaOCl})$ is the irrigant solution universally indicated for chemomechanical root canal preparation due to its antimicrobial and organic material solvent actions. ${ }^{1,2}$ However, $\mathrm{NaOCl}$ adversely affects the mechanical properties of dentin, such as microhardness, elastic modulus, and flexural and fatigue strength. ${ }^{3}$ It may also reduce the adhesion of the root canal sealers ${ }^{4}$ and weaken the bond of some adhesive materials to the dentin. ${ }^{3}$ Moreover, $\mathrm{NaOCl}$ does not favor smear layer removal, which makes it necessary to use a decalcifying agent along with $\mathrm{NaOCl}$. Ethylenediaminetetraacetic acid (EDTA) is the chelating agent most commonly used to remove the smear layer generated during root canal preparation. ${ }^{5}$ However, the use of EDTA associated with $\mathrm{NaOCl}$ leads to the erosion of dentin and reduction in microhardness. ${ }^{6}$ 
Alternative irrigants, among them peracetic acid (PAA), have been researched ${ }^{7}$ with the purpose of improving the cleaning and disinfection of the root canal system. ${ }^{8,9,10}$ PAA is widely used for disinfecting medical equipment ${ }^{11}$ among other items. It is fast and effective against bacteria, fungi, spores, and viruses, even in the presence of organic matter. ${ }^{12}$ PAA has been used as single endodontic irrigant throughout eastern Europe. ${ }^{13}$ A recent study showed that when used as a single endodontic irrigant, $1 \%$ PAA shows an antibacterial efficacy similar to that of $2.5 \% \mathrm{NaOCl}$ and $2 \%$ chlorhexidine against Enterococcus faecalis. ${ }^{9}$ Another study showed that 4\% PAA kills and dissolves significantly mixed biofilms in a manner similar to that of $2.5 \%$ and $5.25 \% \mathrm{NaOCl} .{ }^{14}$ In addition to its antibacterial effectiveness, PAA has the capacity to remove the smear layer when used as a final rinse after the use of $\mathrm{NaOCl}^{10}$ Its antibacterial effectiveness associated with its capacity for removing the smear layer has made PAA a possible alternative to be used as single irrigant, which would simplify and speed up root canal preparation. Nevertheless, while PAA presents the potential for use as a root canal irrigant, ${ }^{8,9}$ there is no evidence of its effect on the cleaning of the root canal and of the quality of the endodontic filling following its use.

The objective of this study was to evaluate the effect of peracetic acid (PAA) as a single irrigant on the smear layer, on the intraradicular dentinal bond strength, and on the penetrability of an epoxy-based resin sealer into the dentinal tubules. The null hypothesis was that there was no difference observed in the above mentioned three parameters in comparison with $\mathrm{NaOCl}-\mathrm{EDTA}-\mathrm{NaOCl}$.

\section{Methodology}

This in vitro study was approved by the Research Ethics Committee of the Araraquara School of Dentistry, UNESP, São Paulo, Brazil (approval number: 20832213.1.0000.5416).

A total of 120 freshly extracted human singlerooted canines were selected and stored in $0.1 \%$ thymol at $4{ }^{\circ} \mathrm{C}$. The teeth were then immersed in distilled water for 24 hours to completely remove thymol residues and were examined under 20x stereomicroscope magnification (Leica Microsystems, Wetzlar, Germany) to discard teeth with fractures and/or cracks. Mesiodistal and buccolingual digital radiographs (Kodak RVG 6100 Digital Radiography System, Marne-la- Vallée, France) were taken to certify that all teeth had only one canal and similar internal anatomy. To prevent dehydration, the teeth were stored in water until use.

The selected teeth were decoronated $16 \mathrm{~mm}$ from the anatomic apex, and the foraminal opening was sealed with resin composite to prevent irrigant extrusion from the apical foramen (closed canal system). ${ }^{15}$ The specimens were randomly distributed into 4 groups $(n=30)$ according to the irrigant used for root canal preparation: 1\% PAA (PAA); $2.5 \% \mathrm{NaOCl}$ (Rioquímica, São José do Rio Preto, SP, Brazil) during instrumentation, followed by final irrigation with $17 \%$ EDTA (Biodinâmica, Ibiporã, Brazil) and 2.5\% NaOCl (NaOCl-EDTA-NaOCl); $2.5 \% \mathrm{NaOCl}(\mathrm{NaOCl}) ;$ and $0.9 \%$ saline solution (JP Indústria Farmacêutica S.A, Riberão Preto, Brazil) as control (SS). In the PAA group, $1 \%$ PAA was freshly prepared by diluting $4 \%$ PAA (Peresal, Profilática, Curitiba, Brazil) with distilled water. ${ }^{16}$ According to the manufacturer, Peresal is composed of $4 \%$ PAA and $26 \%$ hydrogen peroxide.

The root canals were instrumented using ProTaper nickel-titanium rotary instruments (Dentsply Maillefer, Ballaigues, Switzerland) up to size F5 (SX, S1, S2, F1, F2, F3, F4, F5). The working length $(\mathrm{WL})$ was established by inserting a size 10 K-file (Dentsply Maillefer, Ballaingues, Switzerland) into each root canal until it was just visible at the apical foramen and then subtracting $1 \mathrm{~mm}$ from this point. The irrigant solutions were placed in 5 $\mathrm{mL}$ disposable plastic syringes (Ultradent Products Inc., South Jordan, USA), coupled to a Navitip 30 G open-ended irrigation needle (Ultradent) and placed $1 \mathrm{~mm}$ short of the WL. At each change of rotary files, the root canals were irrigated with 2 $\mathrm{mL}$ of irrigant solution for 1 minute in all groups. In $\mathrm{NaOCl}$-EDTA-NaOCl group, after instrumentation, the root canals were irrigated with $3 \mathrm{~mL}$ of $17 \%$ EDTA for 3 minutes, followed by irrigation with $2 \mathrm{~mL}$ of $2.5 \% \mathrm{NaOCl}$ for 1 minute. In the other groups, $5 \mathrm{~mL}$ of distilled water for 4 minutes was used to standardize the time and total volume of 
the irrigants ( 10 minutes and $20 \mathrm{~mL}$, respectively). The root canals were dried using F5 absorbent paper points (ProTaper, Dentsply Maillefer, Ballaigues, Switzerland).

\section{Scanning electron microscopy}

Scanning electron microscopy (SEM) was used to evaluate the smear layer using EVO 50 microscope (Carl Zeiss, Oberkochen, Germany) at $20 \mathrm{kV}$. After root canal preparation, the roots $(n=60)$ were distributed into 4 groups $(n=15)$ and split along their long axis, prepared and evaluated in accordance with the methodology of Faria et al. ${ }^{17}$ Initially, the root canal walls were visualized at 500× magnification in different fields in the apical, middle, and cervical thirds. Three representative SEM photomicrographs were taken at $2000 \times$ magnification in the apical, middle, and cervical thirds of each specimen for analysis of the smear layer. The images were selected in a random-walk manner through the defined sections with instructions to avoid un-instrumented canal surfaces. ${ }^{15}$ The smear layer was scored using the system proposed previously: a) no smear layer with dentinal tubules open; b) small amount of smear layer with some dentinal tubules open; c) a homogenous smear layer covering the root canal wall with only a few dentinal tubules open; d) complete root canal wall covered by a homogenous smear layer with no open dentinal tubules; and e) heavy non-homogenous smear layer covering the complete root canal wall. ${ }^{18}$ Two calibrated examiners analyzed the smear layer independently and blindly (Kappa $>0.9$ ). The scores were compared, and when there was a difference, the evaluators jointly examined the sample and discussed its scoring until they reached an agreement on the final score.

\section{Push-out bond strength test}

After root canal preparation was performed as described above, the remaining roots $(n=60)$ were distributed into 4 groups $(n=15)$ and were filled with the single-cone technique using a F5 gutta-percha point (ProTaper, Dentsply Maillefer, Ballaigues, Switzerland) and AH Plus sealer (Dentsply DeTrey, Konstanz, Germany), with the addition of $0.1 \%$ (by mass) of rhodamine B (Synth, São Bernardo do Campos, Brazil). The sealer was first installed inside the root canal with a lentulo spiral after which the gutta-percha point coated with sealer was inserted into the root canal till the working length. The roots were radiographed from buccolingual and mesiodistal directions to check the length of the filling material and the presence of voids. Excess material was removed with a heated vertical condenser. The roots were stored at $37^{\circ} \mathrm{C}$ and $100 \%$ relative humidity for 7 days to allow the sealers to set.

The push-out test has been used in a previous study. ${ }^{19}$ In our study, the roots were embedded in polyester resin (Maxi Rubber, Diadema, Brazil) and remained intact for 24 hours. The specimens were sectioned perpendicular to their longitudinal axis using a slow-speed diamond saw (Isomet, Buehler Ltd, Lake Bluff, IL, USA) under continuous water spray to prevent frictional heat. The cervical, middle, and apical sections were cut with a thickness of $2.0 \mathrm{~mm}$ and were obtained 1,5 and $10 \mathrm{~mm}$ from the apex, respectively.

The filling material was loaded in the apical to coronal direction using stainless steel plungers that measured $0.5 \mathrm{~mm}$ (apical slices), 0.9 (middle slices) or $1.30 \mathrm{~mm}$ (coronal slices) in diameter. This provided the most extensive coverage of the filling material without touching the canal wall. A compressive load was applied by using a universal test machine (EMIC, São José dos Pinhais, PR, Brazil) at a crosshead speed of $0.5 \mathrm{~mm} / \mathrm{min}$ until debonding occurred. The values at the time of displacement were recorded as a force $(\mathrm{N})$ and were transformed into tension (MPa) using a previously-reported formula: area $=2 \mathrm{pr} \times \mathrm{h}$; where $\mathrm{p}=3.14, \mathrm{r}=$ measured radius of the filling material, and $\mathrm{h}=$ height (in millimeters) of the filling material that was pushed out. ${ }^{20}$

After the push-out test, the specimens were evaluated under a stereomicroscope (Leica Microsystems, Wetzlar, Germany) at 40× magnification to determine the failure mode. The failures were classified according to Huffman et al. ${ }^{21}$ adhesive: along the sealer-dentine interface; cohesive: within the sealer; or mixed: partial adhesive failure along the dentin walls and partial cohesive failure within the sealer. 


\section{Confocal laser scanning microscopy}

Confocal laser scanning microscopy was used to evaluate the penetrability of endodontic sealer into the dentinal tubules. The sections used for the push-out test were polished in a Politriz (Arotec, Cotia, São Paulo, Brazil) polishing machine, by using abrasive paper under running water. The slices were analyzed by using an inverted Leica TCS-SPE confocal laser-scanning microscope (Leica Microsystems $\mathrm{GmbH}$, Mannheim, Germany) at $10 \times$ magnification. The samples were scanned, and the images were recorded with a size of $1024 \times 1024$ pixels. The penetrability of sealer into dentinal tubules was measured twice by one calibrated examiner using the Image J software (National Institutes of Health, NIH, Bethesda, Maryland, USA). The circumference of the root canal and the sections along the canal wall in which the sealer penetrated into the dentinal tubules were measured in micrometers to determine the percentage of sealer penetration into the root canal. ${ }^{22}$

\section{Statistical analysis}

Statistical analysis was performed using the nonparametric Kruskal-Wallis test and the Dunn posttest because the non-normal distribution of data was confirmed in a preliminary analysis. The statistical program GraphPad Prism (GraphPad Software
Inc., San Diego, USA) was used, and all tests were performed with $\alpha=0.05$.

\section{Results}

Table 1 shows the results of the smear layer analysis in all the thirds of root canal dentin using different endodontic irrigants. In all the root thirds, there was no statistical difference between the PAA and $\mathrm{NaOCl}$-EDTA-NaOCl groups $(\mathrm{p}>0.05)$ and both these groups presented lower smear layer values than those of the $\mathrm{NaOCl}$ and saline groups $(\mathrm{p}<0.05)$. There was no difference between the $\mathrm{NaOCl}$ and saline groups $(p>0.05)$. Figure 1 shows the features of the dentin in the different root thirds under treatment by different irrigants.

The bond strength results of the root canal dentin to the sealer containing epoxy resin $\mathrm{AH}$ Plus) are shown in Table 2. In all the root thirds, there was no difference between the PAA and $\mathrm{NaOCl}-E D T A-\mathrm{NaOCl}$ groups $(\mathrm{p}>0.05$ ) and in both these groups, the root canal sealer showed higher values for bond strength to root dentin than those of the $\mathrm{NaOCl}$ and saline groups $(\mathrm{p}<0.05)$. There was no statistically significant difference between the $\mathrm{NaOCl}$ and saline groups ( $\mathrm{p}>0.05$ ). Failure mode analysis showed that mixed failure was predominant in the PAA and $\mathrm{NaOCl}-\mathrm{EDTA}-\mathrm{NaOCl}$

Table 1. Smear layer evaluation after root canal preparation using different irrigant solutions.

\begin{tabular}{|c|c|c|c|c|c|}
\hline Radicular third & Group & Median & Minimum & Maximum & 1 st and $3 r d$ quartiles \\
\hline \multirow{4}{*}{ Cervical } & Peracetic acid & $1^{a}$ & 1 & 3 & $1-1.5$ \\
\hline & $\mathrm{NaOCl}-\mathrm{EDTA}-\mathrm{NaOCl}$ & $1^{a}$ & 1 & 3 & $1-1$ \\
\hline & $\mathrm{NaOCl}$ & $4^{\mathrm{b}}$ & 1 & 5 & $4-4$ \\
\hline & Saline solution & $4^{b}$ & 2 & 5 & $5-3.5$ \\
\hline \multirow{4}{*}{ Middle } & Peracetic acid & $2^{a}$ & 1 & 3 & $1-2$ \\
\hline & $\mathrm{NaOCl}-\mathrm{EDTA}-\mathrm{NaOCl}$ & $1^{a}$ & 1 & 4 & $1-2.5$ \\
\hline & $\mathrm{NaOCl}$ & $4^{b}$ & 1 & 5 & $4-4$ \\
\hline & Saline solution & $4^{b}$ & 2 & 5 & $3-4$ \\
\hline \multirow{4}{*}{ Apical } & Peracetic acid & $1^{a}$ & 1 & 4 & $1-2$ \\
\hline & $\mathrm{NaOCl}-\mathrm{EDTA}-\mathrm{NaOCl}$ & $2^{a}$ & 1 & 4 & $1-3.5$ \\
\hline & $\mathrm{NaOCl}$ & $4^{\mathrm{b}}$ & 1 & 5 & $4-5$ \\
\hline & Saline solution & $5^{b}$ & 4 & 5 & $4-5$ \\
\hline
\end{tabular}

Different superscript letters in the same column indicate a statistically significant difference among the groups in each of the root thirds $(p<0.05)$. 


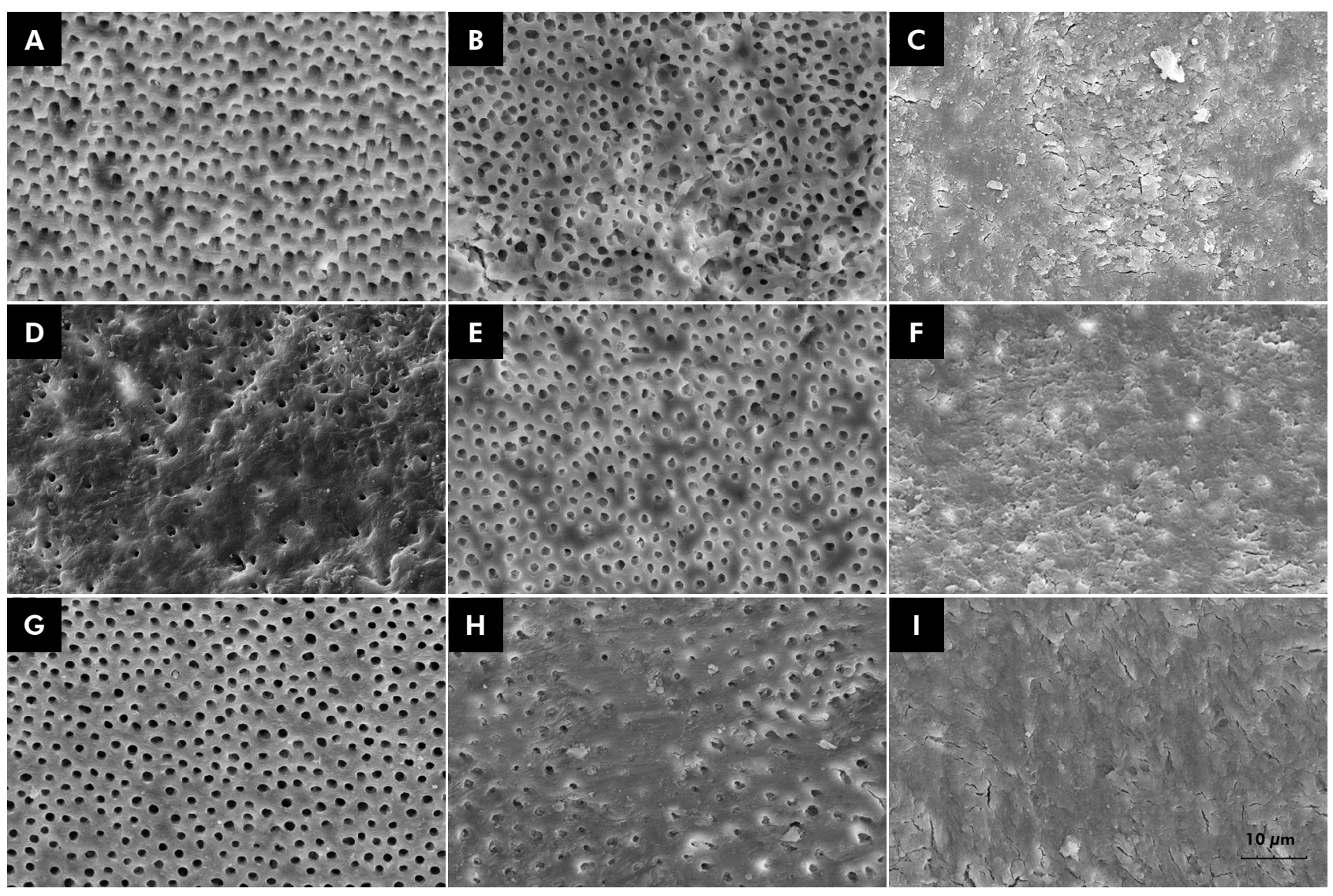

Figure 1. Smear layer on root dentin. Representative images of the PAA group in the cervical (a), middle (d) and apical (g) thirds; of the $\mathrm{NaOCl}$-EDTA-NaOCl group in the cervical (b), middle (e) and apical (h) thirds; and of the $\mathrm{NaOCl}$ and saline groups in the cervical (c), middle ( $f$ ) and apical (i) thirds are shown. Since there was no difference between $\mathrm{NaOCl}$ and saline groups, both groups are represented in the same images. Bar $=10 \mu \mathrm{m}$.

Table 2. Intraradicular dentin bond strength (in $\mathrm{MPa}$ ) after root canal preparation using different irrigant solutions.

\begin{tabular}{|c|c|c|c|c|c|}
\hline Radicular third & Group & Median & Minimum & Maximum & 1 st and 3rd quartiles \\
\hline \multirow{4}{*}{ Cervical } & Peracetic acid & $1.42^{\circ}$ & 2.58 & 1.11 & $1.29-2.08$ \\
\hline & $\mathrm{NaOCl}-\mathrm{EDTA}-\mathrm{NaOCl}$ & $1.80^{\circ}$ & 2.67 & 1.01 & $0.82-0.90$ \\
\hline & $\mathrm{NaOCl}$ & $1.03^{b}$ & 1.39 & 0.54 & $0.70-1.25$ \\
\hline & Saline solution & $0.90^{b}$ & 1.38 & 0.77 & $0.82-1.03$ \\
\hline \multirow{4}{*}{ Middle } & Peracetic acid & $2.12^{a}$ & 3.38 & 1.76 & $2.04-2.19$ \\
\hline & $\mathrm{NaOCl}-\mathrm{EDTA}-\mathrm{NaOCl}$ & $2.46^{\circ}$ & 3.06 & 2.15 & $2.29-2.88$ \\
\hline & $\mathrm{NaOCl}$ & $1.30^{\mathrm{b}}$ & 1.70 & 0.71 & $1.08-1.50$ \\
\hline & Saline solution & $0.99^{b}$ & 1.66 & 0.04 & $0.99-0.85$ \\
\hline \multirow{4}{*}{ Apical } & Peracetic acid & $2.01^{\circ}$ & 2.45 & 1.49 & $1.83-2.24$ \\
\hline & $\mathrm{NaOCl}-\mathrm{EDTA}-\mathrm{NaOCl}$ & $2.44^{\circ}$ & 3.16 & 2.31 & $2.38-2.63$ \\
\hline & $\mathrm{NaOCl}$ & $0.93^{b}$ & 1.43 & 0.63 & $0.72-1.26$ \\
\hline & Saline solution & $0.86^{b}$ & 1.35 & 0.10 & $0.75-1.11$ \\
\hline
\end{tabular}

Different superscript letters in the same column indicate a statistically significant difference among the groups in each of the root thirds $(p<0.05)$. 
Table 3. Penetrability of root canal sealer into dentinal tubules (in percentage) after root canal preparation using different irrigant solutions.

\begin{tabular}{|c|c|c|c|c|c|}
\hline Radicular third & Group & Median & Minimum & Maximum & 1 st and 3rd quartiles \\
\hline \multirow{4}{*}{ Cervical } & Peracetic acid & $60.29^{a}$ & 67.39 & 38.27 & $53.21-64.00$ \\
\hline & $\mathrm{NaOCl}-\mathrm{EDTA}-\mathrm{NaOCl}$ & $60.57^{a}$ & 67.43 & 42.91 & $57.12-64.79$ \\
\hline & $\mathrm{NaOCl}$ & $27.48^{b}$ & 38.19 & 14.07 & $22.65-32.80$ \\
\hline & Saline solution & $38.83^{b}$ & 42.49 & 32.10 & $35.71-40.96$ \\
\hline \multirow{4}{*}{ Middle } & Peracetic acid & $56.12^{a}$ & 60.65 & 48.73 & $51.18-58.69$ \\
\hline & $\mathrm{NaOCl}-\mathrm{EDTA}-\mathrm{NaOCl}$ & $52.77^{a}$ & 73.12 & 39.43 & $45.42-60.25$ \\
\hline & $\mathrm{NaOCl}$ & $38.97^{b}$ & 46.44 & 29.92 & $37.93-43.06$ \\
\hline & Saline solution & $39.26^{b}$ & 47.09 & 27.80 & $33.52-39.85$ \\
\hline \multirow{4}{*}{ Apical } & Peracetic acid & $49.76^{\circ}$ & 67.91 & 36.01 & $44.09-60.26$ \\
\hline & $\mathrm{NaOCl}-\mathrm{EDTA}-\mathrm{NaOCl}$ & $47.90^{\circ}$ & 62.29 & 45.45 & $47.34-55.93$ \\
\hline & $\mathrm{NaOCl}$ & $34.58^{b}$ & 46.14 & 27.58 & $31.72-39.54$ \\
\hline & Saline solution & $36.65^{b}$ & 43.90 & 30.21 & $33.77-40.07$ \\
\hline
\end{tabular}

Different superscript letters in the same column indicate a statistically significant difference among the groups in each of the root thirds ( $p<0.05)$.

groups and that adhesive failure predominated in the saline and $\mathrm{NaOCl}$ groups, irrespective of the root third being analyzed.

Table 3 shows the results of the penetration of root canal sealer containing epoxy resin (AH Plus) into root canal dentin, in all root thirds using different endodontic irrigants. There was no difference in sealer penetration into dentin between the PAA and $\mathrm{NaOCl}-\mathrm{EDTA}-\mathrm{NaOCl}$ groups $(\mathrm{p}>0.05)$. In all the root thirds for both these groups ( $p>0.05)$, the root canal sealer showed higher values of penetration into root dentin than those of the $\mathrm{NaOCl}$ and saline groups $(p<0.05)$. There was no difference between the $\mathrm{NaOCl}$ and saline groups $(p>0.05)$. Figure 2 illustrates the root canal sealer penetration into dentin.

\section{Discussion}

In the present study, we evaluated the effect of PAA as a single irrigant on the smear layer, on the intraradicular dentinal bond strength, and on the penetrability of an epoxy-based resin sealer into the dentinal tubules as compared to the combined use of NaOCl-EDTA-NaOCl. The null hypothesis was rejected regarding the smear layer but was accepted for intraradicular dentin bond strength and penetrability.
The smear layer formed during root canal preparation is composed of both inorganic and organic substances that may also contain bacteria and their by-products. The smear layer may prevent intracanal medications from penetrating into the root canal system and influence the adaptation, ${ }^{5}$ bond, ${ }^{6}$ and penetrability of root canal sealers into root dentin. ${ }^{23}$ The protocol most commonly used for removing the smear layer is the alternate use of $\mathrm{NaOCl}$ and EDTA. ${ }^{5,15}$

Till date, there are no studies in the literature that evaluate the degree of cleaning of root dentin provided by the use of $1 \%$ PAA as a single root canal irrigant. The present study showed that the use of $1 \%$ PAA as a single irrigant solution provided smear layer removal in all root thirds in a manner similar to that of the NaOCl-EDTA-NaOCl group. These results are in line with those of studies that have shown the capacity of PAA for smear layer removal when used as a final irrigant solution after instrumentation. ${ }^{10,16,24}$ The first study ${ }^{10}$ showed that $2.25 \%$ PAA used for 3 minutes after root canal instrumentation led to smear layer removal in a similar manner to that of $17 \%$ EDTA. The other studies $^{16,24}$ showed that PAA at concentrations of $0.5 \%, 1 \%$ and $2.25 \%$ used for 60 seconds in contact with dentin led to the dissolution of the smear layer 


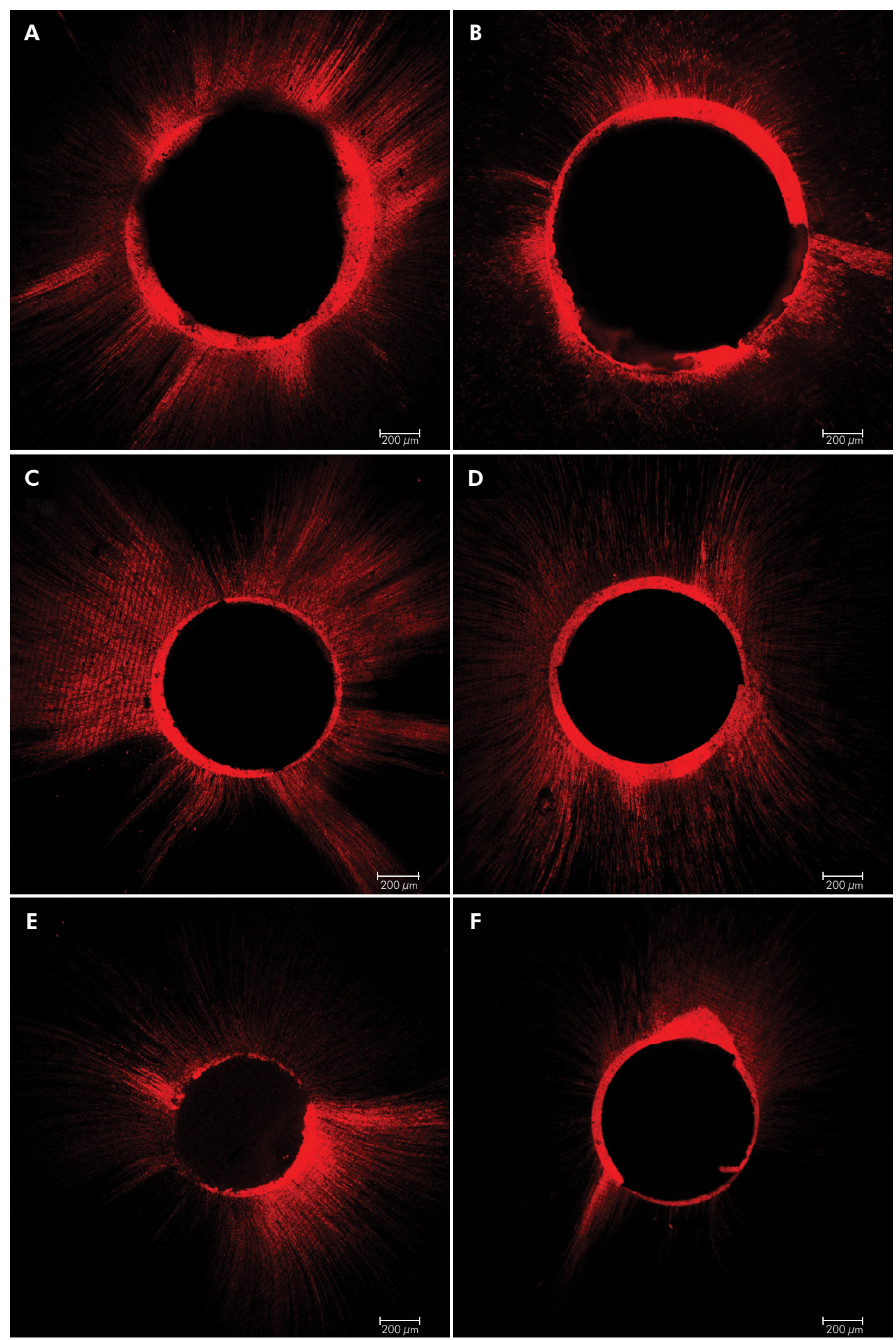

Figure 2. Penetrability of root canal sealer into dentinal tubules. Since there was no difference between PAA and $\mathrm{NaOCl-EDTA-NaOCl}$ groups in relation to sealer penetrability, both these groups are represented in the same image in the cervical (a), middle (c) and apical (e) thirds. The groups of $\mathrm{NaOCl}$ and saline are represented in the same image in the cervical (b), middle (d) and apical (f) thirds. Bar $=200 \mu \mathrm{m}$. 
as effectively as $17 \%$ EDTA. PAA is commercially available in the form of an aqueous solution, in which it is in equilibrium with hydrogen peroxide and acetic acid. The acetic acid component is probably responsible for the dissolution of the smear layer, as it forms complexes with calcium that are easily soluble in water. ${ }^{10,16}$ On the other hand, both PAA and NaOCl-EDTA-NaOCl were not able to completely remove the smear layer in the closed canal system used in the present study, which more accurately simulated the actual in vivo application of the irrigants. ${ }^{15}$

The volume of the final irrigation solutions is another important factor that can influence the smear layer removal. ${ }^{24}$ In the present study, different irrigation protocols were used and the total volume of the irrigants was standardized as $20 \mathrm{~mL}$ during and after instrumentation.

One limitation of this study was that the SEM evaluation of smear layer can only compare the amount of open dentinal tubules in a single moment; consequently, the examiners were neither able to determine the extent of already present sclerotic dentin nor if the analyzed areas had already been touched by endodontic instruments with consequent formation of smear layer. ${ }^{10,25}$ Due to this, the model with which the teeth were instrumented, cleaved, and evaluated by SEM was a proposed structure. After the teeth halves were placed back together, the specimens were irrigated with the final root canal irrigant and the post-treatment SEM images were obtained to evaluate the effects of the final irrigation. ${ }^{25}$ In the present study, this model was not used because the PAA was used during instrumentation and not as a final irrigant. Additionally, we used a random distribution of specimens with the aim to ensure that all groups showed the same distribution of sclerotic dentin and other features. This helped us avoid bias when comparing the cleaning capacity of root canal irrigants.

In the present study, PAA was used in the concentration of $1 \%$, which has an antibacterial efficacy similar to that of $2.5 \% \mathrm{NaOCl}$ and $2 \%$ chlorhexidine against E. faecalis, ${ }^{9}$ and an capacity for smear layer removal when used as final irrigant. ${ }^{16,24}$ Concentrations higher than $1 \%$ were not used because $2.25 \%$ PAA causes dentin erosion ${ }^{10}$ and greater removal of some mineral components of the dentin when compared to $17 \%$ EDTA. ${ }^{26}$ In addition, $2.25 \%$ PAA used as the final rinse results in lower bond strength of AH Plus to dentin when compared to EDTA. ${ }^{27}$

In addition to antimicrobial activity and smear layer removal, among other requisites, irrigants must favor or at least not harm the bond of root canal sealers to root dentin. ${ }^{28}$ The high bond strength of root canal sealers to dentin helps maintain the integrity of the sealer-dentin interface and prevents debonding of the filling material during the operative procedures. ${ }^{21}$ The push-out test has been widely used to evaluate the bond strength of filling materials to root dentin. ${ }^{4,29}$ This test has been performed in teeth filled with a combination of gutta-percha and sealer ${ }^{6,19,20,30,31,32}$ or sealer alone. ${ }^{4,28,29,33}$.This combination may be a limitation of the present study because this soft-core material undergoes plastic deformation under load. ${ }^{32}$ However, in clinical practice, the root canals are not obturated without gutta-percha because AH Plus sets to a hard consistency which would make retreatment difficult. ${ }^{31}$ Thus, to simulate clinical conditions, the root canals were filled with gutta-percha cone and AH Plus in this study. In addition, specimens with oval-shaped root canals were not used; we selected roots with round cross-sections to have a similar amount of sealer wrapped around the gutta-percha cone, in accordance with previous studies. . $^{27,31}$

Endodontic irrigants may affect the bond of sealers to root dentin ${ }^{4}$ because they may lead to different demineralization pattern $\mathrm{s}^{16}$ and may change the composition of the dentin surface. ${ }^{26}$ Studies have shown that AH Plus has a high bond strength to dentin when irrigation protocols using EDTA are used. . $^{4,6,28,34}$ In the present study, there was no difference between the $1 \%$ PAA and NaOCl-EDTA-NaOCl groups, and in both groups, the AH Plus sealer showed higher values for bond strength to root dentin than those of the $\mathrm{NaOCl}$ and saline groups. These results are in agreement with previous studies that showed that the use of irrigants with the capacity to remove the smear layer increased the bond strength of resinbased sealers to root dentin. ${ }^{4,6,34}$ They are also in agreement with the results of a recent study that showed there was no difference in the push-out 
bond strength of AH Plus when 17\% EDTA, 2.25\% PAA or $10 \%$ citric acid were used as the final irrigant solution..$^{29}$ The lower bond strength of AH Plus to dentin was observed in the $\mathrm{NaOCl}$ and saline groups, as has also been observed in other studies. ${ }^{6,28,34}$ This probably occurred because there was no smear layer removal and consequently, there was no exposure of the collagen network. ${ }^{34}$ According to the literature, the high bond strength of $\mathrm{AH}$ Plus to dentin is related to its chemical bond with the collagen in dentin., ${ }^{4,30}$ On the other hand, a recent study showed that final irrigation with 17\% EDTA or with 1\% PAA did not improve the bond strength of AH Plus to root dentin in comparison to distilled water. ${ }^{33}$ This difference may be attributed to the variation in study design; the previous study demonstrated the use 17\% EDTA and $1 \%$ PAA as a final irrigant, filled the root canal with sealer only, and used a plunger with a single diameter to perform the push-out test. ${ }^{33}$ In contrast, the present researchers used 1\% PAA as a single irrigant during root canal preparation, filled the root canal with AH Plus and gutta-percha, and used plungers with a specific dimension for different root thirds. The use of plungers of a specific dimension in different root thirds ensured that the dislocation force was not influenced by the punch diameter. ${ }^{32}$

In this study, the PAA solution used was obtained from the dilution of Peresal which is composed of $4 \%$ PAA and $26 \%$ hydrogen peroxide, that is, with a high concentration of hydrogen peroxide. The same solution was used for irrigation of the prepared post space, after which high residual concentrations of oxygen were observed..$^{35}$ Oxygen is known to inhibit the complete polymerization of resinous materials ${ }^{36}$ that are used in the cementation of the intracanal post. For this reason, push-out tests should be performed to evaluate the effect of PAA used during root canal preparation on the adhesion of intracanal post cemented with resin cement, and if necessary, perform another treatment in the post space before cementation of the post.

The success of endodontic treatment depends on the disinfection of the root canal system and the prevention of reinfection..$^{1}$ Therefore, penetration of the sealer into dentinal tubules is important due to its antibacterial activity as it blocks microorganisms within the dentinal tubules. ${ }^{22}$ However, it should be emphasized that sealer penetration into the dentinal tubules has no influence in the marginal infiltration. ${ }^{37}$ Confocal laser scanning microscope (CLSM) has been employed for evaluating the sealer penetration..$^{38-40}$ CLSM has several advantages, such as being able to use non-decalcified or hard tissue samples that do not require a specific sectioning technique (sputter coating), providing detailed information about the presence and distribution of sealers at relatively low magnification through the use of fluorescent rhodamine-marked sealers, and allowing the exclusion of artifacts from the sample. ${ }^{38}$ In the present study, sealer penetration into root dentin was influenced by the irrigant used. In the groups irrigated with PAA or $\mathrm{NaOCl}$-EDTA-NaOCl, there was greater penetration of the sealer into dentin when compared with the $\mathrm{NaOCl}$ and saline groups. These findings are coherent with the results of the smear layer removal; the groups that presented higher smear layer removal values also presented higher root canal sealer penetration values.

Considering the factors that were evaluated, we found that $1 \%$ PAA has the potential to be used as a single irrigant solution in root canals. However, further studies are required to evaluate the potential for organic tissue dissolution and other effects on root dentin by the use of $1 \%$ PAA solution.

\section{Conclusion}

In summary, the use of $1 \%$ PAA as a single root canal irrigant provided smear layer removal, intraradicular dentine bond strength, and penetrability of an epoxybased resin sealer into dentinal tubules similar to that of a combined irrigation method consisting of using $2.5 \% \mathrm{NaOCl}$ during instrumentation, followed by final irrigation with $17 \%$ EDTA and $2.5 \% \mathrm{NaOCl}$.

\section{Acknowledgments}

The study was supported by grant 2014/22549-7 from the São Paulo State Research Foundation (FAPESP), National Council for Scientific and Technological Development (CNPq), and Coordenação de Aperfeiçoamento de Pessoal de Nível Superior Brasil (CAPES) - Finance Code 001. 
Effect of peracetic acid used as single irrigant on the smear layer, adhesion, and penetrability of AH Plus

\section{References}

1. Haapasalo M, Shen Y, Qian W, Gao Y. Irrigation in endodontics. Dent Clin North Am. 2010 Apr;54(2):291-312. https://doi.org/10.1016/i.cden.2009.12.001

2. Ye WH, Fan B, Purcell W, Meghil MM, Cutler CW, Bergeron BE, et al. Anti-biofilm efficacy of root canal irrigants against in-situ Enterococcus faecalis biofilms in root canals, isthmuses and dentinal tubules. J Dent. 2018 Dec;79(1):68-76. https://doi.org/10.1016/i.jdent.2018.10.002

3. Pascon FM, Kantovitz KR, Sacramento PA, Nobre-dos-Santos M, Puppin-Rontani RM. Effect of sodium hypochlorite on dentine mechanical properties. A review. J Dent. 2009 Dec;37(12):903-8. https://doi.org/10.1016/i.jdent.2009.07.004

4. Neelakantan P, Sharma S, Shemesh H, Wesselink PR. Influence of Irrigation Sequence on the Adhesion of Root Canal Sealers to Dentin: A Fourier Transform Infrared Spectroscopy and Push-out Bond Strength Analysis. J Endod. 2015 Jul;41(7):1108-11. https://doi.org/10.1016/i.joen.2015.02.001

5. Violich DR, Chandler NP. The smear layer in endodontics - a review. Int Endod J. 2010 Jan;43(1):2-15. https://doi.org/10.1111/j.1365-2591.2009.01627.x

6. Aranda-Garcia AJ, Kuga MC, Vitorino KR, Chávez-Andrade GM, Duarte MA, Bonetti-Filho l, et al. Effect of the root canal final rinse protocols on the debris and smear layer removal and on the push-out strength of an epoxy-based sealer. Microsc Res Tech. 2013 May;76(5):533-7. https://doi.org/10.1002/jemt.22196

7. Viola KS, Rodrigues EM, Tanomaru-Filho M, Carlos IZ, Ramos SG, Guerreiro-Tanomaru JM, et al. Cytotoxicity of peracetic acid: evaluation of effects on metabolism, structure and cell death. Int Endod J. 2018 May;51 Suppl 4:e264-77. https://doi.org/10.1111/iej.12750

8. Cord CB, Velasco RV, Ribeiro Melo Lima LF, Rocha DG, da Silveira Bueno CE, Pinheiro SL. Effective analysis of the use of peracetic acid after instrumentation of root canals contaminated with Enterococcus faecalis. J Endod. 2014 Aug;40(8):1145-8. https://doi.org/10.1016/i.joen.2014.02.007

9. Dornelles-Morgental R, Guerreiro-Tanomaru JM, de Faria-Júnior NB, Hungaro-Duarte MA, Kuga MC, Tanomaru-Filho M. Antibacterial efficacy of endodontic irrigating solutions and their combinations in root canals contaminated with Enterococcus faecalis. Oral Surg Oral Med Oral Pathol Oral Radiol Endod. 2011 Sep;112(3):396-400. https://doi.org/10.1016/j.tripleo.2011.02.004

10. Lottanti S, Gautschi H, Sener B, Zehnder M. Effects of ethylenediaminetetraacetic, etidronic and peracetic acid irrigation on human root dentine and the smear layer. Int Endod J. 2009 Apr;42(4):335-43. https://doi.org/10.1111/j.1365-2591.2008.01514.x

11. Kovaleva J, Degener JE, van der Mei HC. Mimicking disinfection and drying of biofilms in contaminated endoscopes. J Hosp Infect. 2010 Dec;76(4):345-50. https://doi.org/10.1016/i.jhin.2010.07.008

12. Kitis M. Disinfection of wastewater with peracetic acid: a review. Environ Int. 2004 Mar;30(1):47-55. https://doi.org/10.1016/S0160-4120(03)00147-8

13. Kühlfluck I, Klammt J. [Suitability of peracetic acid for root canal disinfection]. Stomatol DDR. 1980 Aug;30(8):558-63.

14. Ordinola-Zapata R, Bramante CM, Garcia RB, de Andrade FB, Bernardineli N, de Moraes IG, et al. The antimicrobial effect of new and conventional endodontic irrigants on intra-orally infected dentin. Acta Odontol Scand. 2013 May-Jul; 71(3-4):424-31. https://doi.org/10.3109/00016357.2012.690531

15. Parente JM, Loushine RJ, Susin L, Gu L, Looney SW, Weller RN, et al. Root canal debridement using manual dynamic agitation or the EndoVac for final irrigation in a closed system and an open system. Int Endod J. 2010 Nov;43(11):1001-12. https://doi.org/10.1111/i.1365-2591.2010.01755.x

16. De-Deus G, Souza EM, Marins JR, Reis C, Paciornik S, Zehnder M. Smear layer dissolution by peracetic acid of low concentration. Int Endod J. 2011 Jun;44(6):485-90. https://doi.org/10.1111/j.1365-2591.2010.01847.x

17. Faria G, Kuga MC, Ruy AC, Aranda-Garcia AJ, Bonetti-Filho I, Guerreiro-Tanomaru JM, et al. The efficacy of the selfadjusting file and ProTaper for removal of calcium hydroxide from root canals. J Appl Oral Sci. 2013 Jul-Aug;21 (4):346-50. https://doi.org/10.1590/1678-775720130034

18. Hülsmann M, Rümmelin C, Schäfers F. Root canal cleanliness after preparation with different endodontic handpieces and hand instruments: a comparative SEM investigation. J Endod. 1997 May;23(5):301-6. https://doi.org/10.1016/S0099-2399(97)80410-4

19. Magro MG, Kuga MC, Aranda-Garcia AJ, Victorino KR, Chávez-Andrade GM, Faria G, et al. Effectiveness of several solutions to prevent the formation of precipitate due to the interaction between sodium hypochlorite and chlorhexidine and its effect on bond strength of an epoxy-based sealer. Int Endod J. 2015 May;48(5):478-83. https://doi.org/10.1111/iej.12337

20. Skidmore LJ, Berzins DW, Bahcall JK. An in vitro comparison of the intraradicular dentin bond strength of Resilon and gutta-percha. J Endod. 2006 Oct;32(10):963-6. https://doi.org/10.1016/i.joen.2006.03.020 PMID:16982274

21. Huffman BP, Mai S, Pinna L, Weller RN, Primus CM, Gutmann JL, et al. Dislocation resistance of ProRoot Endo Sealer, a calcium silicatebased root canal sealer, from radicular dentine. Int Endod J. 2009 Jan;42(1):34-46. https://doi.org/10.1111/i.1365-2591.2008.01490.x 
Keine KC, Kuga MC, Tormin FBC, Venção AC, Duarte MAH, Chávez-Andrade GM et al.

22. Amoroso-Silva PA, Guimarães BM, Marciano MA, Duarte MA, Cavenago BC, Ordinola-Zapata R, et al. Microscopic analysis of the quality of obturation and physical properties of MTA Fillapex. Microsc Res Tech. 2014 Dec;77(12):1031-6. https://doi.org/10.1002/jemt.22432

23. Kokkas AB, Boutsioukis AC, Vassiliadis LP, Stavrianos CK. The influence of the smear layer on dentinal tubule penetration depth by three different root canal sealers: an in vitro study. J Endod. 2004 Feb;30(2):100-2. https://doi.org/10.1097/00004770-200402000-00009

24. Ulusoy OI, Zeyrek S, Çelik B. Evaluation of smear layer removal and marginal adaptation of root canal sealer after final irrigation using ethylenediaminetetraacetic, peracetic, and etidronic acids with different concentrations. Microsc Res Tech. 2017 Jul;80(7):687-92. https://doi.org/10.1002/jemt.22851

25. Schmidt TF, Teixeira CS, Felippe MC, Felippe WT, Pashley DH, Bortoluzzi EA. Effect of Ultrasonic Activation of Irrigants on Smear Layer Removal. J Endod. 2015 Aug;41(8):1359-63. https://doi.org/10.1016/i.joen.2015.03.023

26. Cobankara FK, Erdogan H, Hamurcu M. Effects of chelating agents on the mineral content of root canal dentin. Oral Surg Oral Med Oral Pathol Oral Radiol Endod. 2011 Dec;112(6):e149-54. https://doi.org/10.1016/i.tripleo.2011.06.037

27. Verma D, Taneja S, Kumari M. Efficacy of different irrigation regimes on the push-out bond strength of various resin-based sealers at different root levels: An in vitro study. J Conserv Dent. 2018 Mar-Apr;21(2):125-9. https://doi.org/10.4103/JCD.JCD_337_16

28. Vilanova WV, Carvalho-Junior JR, Alfredo E, Sousa-Neto MD, Silva-Sousa YT. Effect of intracanal irrigants on the bond strength of epoxy resin-based and methacrylate resin-based sealers to root canal walls. Int Endod J. 2012 Jan;45(1):42-8. https://doi.org/10.1111/j.1365-2591.2011.01945.x

29. Carvalho NK, Prado MC, Senna PM, Neves AA, Souza EM, Fidel SR, et al. Do smear-layer removal agents affect the push-out bond strength of calcium silicate-based endodontic sealers? Int Endod J. 2017 Jun;50(6):612-9. https://doi.org/10.1111/iej.12662 PMID:27214521

30. Fisher MA, Berzins DW, Bahcall JK. An in vitro comparison of bond strength of various obturation materials to root canal dentin using a push-out test design. J Endod. 2007 Jul;33(7):856-8. https://doi.org/10.1016/i.joen.2007.02.011

31. Guneser MB, Arslan D, Dincer AN, Er G. Effect of sodium hypochlorite irrigation with or without surfactants on the bond strength of an epoxy-based sealer to dentin. Clin Oral Investig. 2017 May;21(4):1259-65. https://doi.org/10.1007/s00784-016-1885-1

32. Pane ES, Palamara JE, Messer HH. Critical evaluation of the push-out test for root canal filling materials. J Endod. 2013 May;39(5):669-73. https://doi.org/10.1016/i.joen.2012.12.032

33. Tuncel B, Nagas E, Cehreli Z, Uyanik O, Vallittu P, Lassila L. Effect of endodontic chelating solutions on the bond strength of endodontic sealers. Braz Oral Res. 2015;29(1):1-6. https://doi.org/10.1590/1807-3107BOR-2015.vol29.0059

34. Neelakantan P, Varughese AA, Sharma S, Subbarao CV, Zehnder M, De-Deus G. Continuous chelation irrigation improves the adhesion of epoxy resin-based root canal sealer to root dentine. Int Endod J. 2012 Dec;45(12):1097-102. https://doi.org/10.1111/j.1365-2591.2012.02073.x

35. Belizário LG, Kuga MC, Castro-Núñez GM, Escalante-Otárola WG, Só MV, Pereira JR. Effects of different peracetic acid formulations on post space radicular dentin. J Prosthet Dent. 2018 Jul;120(1):92-8. https://doi.org/10.1016/i.prosdent.2017.08.002

36. Rueggeberg FA, Margeson DH. The effect of oxygen inhibition on an unfilled/filled composite system. J Dent Res. 1990 Oct;69(10):1652-8. https://doi.org/10.1177/00220345900690100501

37. De-Deus G, Brandão MC, Leal F, Reis C, Souza EM, Luna AS, et al. Lack of correlation between sealer penetration into dentinal tubules and sealability in nonbonded root fillings. Int Endod J. 2012 Jul;45(7):642-51. https://doi.org/10.1111/i.1365-2591.2012.02023.x

38. Dash AK, Farista S, Dash A, Bendre A, Farista S. Comparison of Three Different Sealer Placement Techniques: An In vitro Confocal Laser Microscopic Study. Contemp Clin Dent. 2017 Apr-Jun;8(2):310-4. https://doi.org/10.4103/ccd.ccd_1109_16

39. Machado R, Garcia LD, da Silva Neto UX, Cruz Filho AM, Silva RG, Vansan LP. Evaluation of 17\% EDTA and 10\% citric acid in smear layer removal and tubular dentin sealer penetration. Microsc Res Tech. 2018 Mar;81(3):275-82. https://doi.org/10.1002/jemt.22976

40. Tedesco M, Chain MC, Bortoluzzi EA, da Fonseca Roberti Garcia L, Alves AM, Teixeira CS. Comparison of two observational methods, scanning electron and confocal laser scanning microscopies, in the adhesive interface analysis of endodontic sealers to root dentine. Clin Oral Investig. 2018 Jul;22(6):2353-61. https://doi.org/10.1007/s00784-018-2336-y 